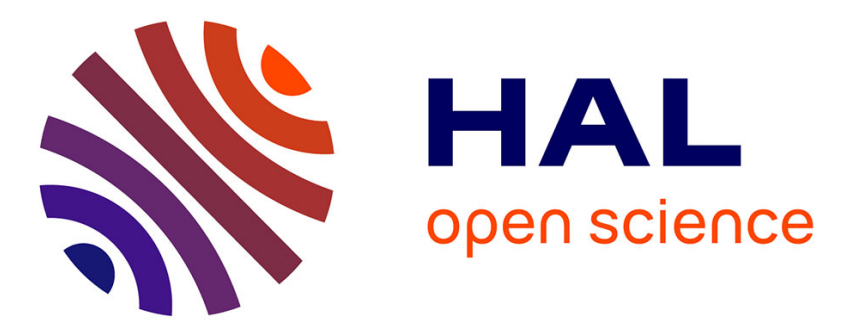

\title{
Influence of impregnation method on metal retention of CCB-treated wood in slow pyrolysis process
}

\author{
Silao Esperance Kinata, Khaled Loubar, Amine Bouslamti, Christophe \\ Belloncle, Mohand Tazerout
}

\section{- To cite this version:}

Silao Esperance Kinata, Khaled Loubar, Amine Bouslamti, Christophe Belloncle, Mohand Tazerout. Influence of impregnation method on metal retention of CCB-treated wood in slow pyrolysis process. Journal of Hazardous Materials, 2012, 233-234, pp.172-176. 10.1016/j.jhazmat.2012.07.011 . hal00935912

\section{HAL Id: hal-00935912 \\ https://hal.science/hal-00935912}

Submitted on 6 Jul 2021

HAL is a multi-disciplinary open access archive for the deposit and dissemination of scientific research documents, whether they are published or not. The documents may come from teaching and research institutions in France or abroad, or from public or private research centers.
L'archive ouverte pluridisciplinaire HAL, est destinée au dépôt et à la diffusion de documents scientifiques de niveau recherche, publiés ou non, émanant des établissements d'enseignement et de recherche français ou étrangers, des laboratoires publics ou privés.

\section{(c)(1)}

Distributed under a Creative Commons Attribution| 4.0 International License 


\title{
Influence of impregnation method on metal retention of CCB-treated wood in slow pyrolysis process
}

\author{
Silao Espérance Kinata ${ }^{\mathrm{a}, *}$, Khaled Loubar ${ }^{\mathrm{a}}$, Amine Bouslamti ${ }^{\mathrm{b}}$, Christophe Belloncle ${ }^{\mathrm{b}}$, Mohand Tazerout ${ }^{\mathrm{a}}$
}

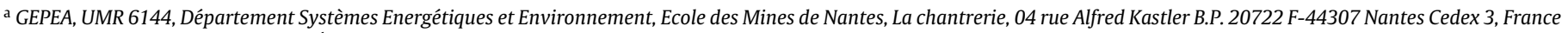

${ }^{\mathrm{b}}$ LUNAM Université, Ecole Supérieure du Bois, rue Christian PAUC, B.P. 10605, 44306 Nantes Cedex, France

\begin{abstract}
In the present work, the effects of copper, chromium and boron on the pyrolysis of wood and their distribution in the pyrolysis products were investigated. For this, the wood has been impregnated with chromium-copper-boron (CCB). In addition, to describe the effects of impregnation method, vacuumpressure and dipping methods were also conducted. Thermogravimetric analysis (TGA) results show that an increase in the final residue and decrease in degradation temperature on both methods of treated wood compared to untreated wood. Then, slow pyrolysis experiments were carried out in a laboratory reactor. The mass balance of pyrolysis products is confirmed by TGA. Furthermore, the concentration of metals in the final residue is measured by inductively coupled plasma mass spectroscopy (ICP-MS). The results show that the final residue contains more than $45 \%$ of the initial amount of metal present in the treated wood. The phenomenon is more pronounced with vacuum-pressure treated wood. The heating values of pyrolysis products were analyzed. The heating value of charcoal obtained from treated and untreated wood is approximately same. But the heating value of tar from untreated wood is higher than the heating value of the tar from treated wood.
\end{abstract}

\section{Introduction}

Waterborne salts have been used to preserve wood and to extend its life service until 20-50 years, depending on the method of treatment and the salts preservative. Copper based formulations such as CCA (chromium, copper, arsenic) or CCB (chromium, copper, boron) are the most important and widely used commercial preservatives [1]. After impregnation by vacuum-pressure method or by dipping method, the metal compounds are fixed on the cell walls of the wood matrix. Substantial amounts of CCA/CCB remain in the wood for many years, and the disposal of waste wood is a

\footnotetext{
* Corresponding author. Tel.: +33 251858288; fax: +33 251858299

E-mail address: Esperance.Kinata@mines-nantes.fr (S.E. Kinata).
}

growing problem in Europe and United States. Telephone poles, timber from landscape and cooling, cable drums and wooden silos generate treated wood wastes which are classified as hazardous industrial waste by the European Commission. From 1998 to 2006 , the amount of treated wood waste was estimated to $2.59 \mathrm{Mt} / \mathrm{year}$ which is $27 \%$ of the hazardous wastes in France [2].

Several alternatives for disposal of treated-wood waste had been studied in the literature $[3,4]$. Slow pyrolysis seems to be a promising approach for the disposal problem. One major advantage of slow pyrolysis is to capture most heavy metals in the charcoal and also to reduce the pollutant in gas drastically which is responsible of environmental pollution. Helsen et al. [5-7] have studied extensively low temperature pyrolysis of CCA-treated wood. Their results suggest that pyrolysis at $300^{\circ} \mathrm{C}$ for $20 \mathrm{~min}$ results in zero metal release $(\mathrm{Cu}, \mathrm{Cr}, \mathrm{As})$ in gas, but the observations are 
inconclusive due to the high experimental uncertainty. Welthe et al. [8] also investigated the impact of CCB wood preservatives on the flash pyrolysis of biomass. The yields of pyrolysis products were similar to those obtained for untreated wood. Even in the presence of high boron content there was only small decrease of the gas yield and a small increase of the charcoal yield. Fu et al. [9] investigated the influence of several inorganic salts $\left(\mathrm{K}_{2} \mathrm{Cr}_{2} \mathrm{O}_{7}, \mathrm{CrO}_{3}\right.$ and $\left.\mathrm{CuSO}_{4}\right)$ on the pyrolysis of southern pine wood at $350{ }^{\circ} \mathrm{C}$ for $30 \mathrm{~min}$. The yield of pyrolysis tar from $\mathrm{K}_{2} \mathrm{Cr}_{2} \mathrm{O}_{7}$-treated wood and $\mathrm{CuSO}_{4}$-treated wood was similar to that from untreated wood. Correspondingly, the yield of charcoal from treated wood was found to be close to that from untreated wood. For $\mathrm{CrO}_{3}$ and $\mathrm{CrO}_{3}+\mathrm{CuSO}_{4}$ treated wood, the yields of pyrolysis fractions were quite different from those of untreated wood. Indeed, the yield of tar decreased drastically and the yield of charcoal increased around 50\% from treated wood compared to untreated wood. The thermogravimetric analysis (TGA) curves of treated wood shifted to lower temperatures. The treated samples decomposed fast at lower temperatures, followed by a slower thermal decomposition at higher temperature, offering high final charcoal yield. The $\mathrm{CrO}_{3}$ treated wood exhibited the most significant effect and the same phenomenon was also apparent for $\mathrm{K}_{2} \mathrm{Cr}_{2} \mathrm{O}_{7}$.

To our knowledge, there is not much research focused on the pyrolysis product from CCB-treated wood. Thus, in the present study slow pyrolysis was performed to investigate the effect of CCB salts on the pyrolysis of wood and the distribution of each element $(\mathrm{Cu}, \mathrm{Cr}$ and $\mathrm{B})$ in the pyrolysis products. Therefore, in the first step the influence of impregnation method in pyrolysis of wood was investigated and in the second step the effect of salts of CCB in pyrolysis of wood was also discussed. This study is aided by the use of thermogravimetric analysis. The heating value was analyzed by a bomb calorimeter to determine the energy value of pyrolysis products obtained.

\section{Materials and methods}

\subsection{Sample preparation}

The type of wood used in the present study is a mixture of scots pine (Pinus sylvestris), maritime pine wood (Pinus pinaster) and douglas (Pseudotsuga menziesii). The crushed wood chips (mixture of sapwood and heartwood) were between 1 and $2 \mathrm{~mm}$ thick. The mixture were impregnated with $5 \% \mathrm{CCB}$ solution $\left(34 \% \mathrm{CuSO}_{4}\right.$, $37.3 \% \mathrm{KCr}\left(\mathrm{SO}_{4}\right)_{2}$ and $\left.28.7 \% \mathrm{H}_{3} \mathrm{BO}_{3}\right)$ according to the prescribed formulae used for waterborne of CCB preservatives [10]. For the vacuum-pressure method, the wood chips and the preservative solution were mixed and placed in the autoclave which was hermetically sealed, a vacuum of $0.09 \mathrm{MPa}$ was applied for $10 \mathrm{~min}$. Subsequently, the autoclave was pressurized by compressed air: $0.8 \mathrm{MPa}$ for $60 \mathrm{~min}$. Samples were removed from the autoclave and dried in a conventional oven with air circulation at a temperature of $105^{\circ} \mathrm{C}$ for $72 \mathrm{~h}$. In the case of dipping method, the wood chips were completely submerged in a tank of preservative solution for $24 \mathrm{~h}$. Then, the samples were removed from the tank and dried in a conventional oven with air circulation at a temperature of $75^{\circ} \mathrm{C}$ for $120 \mathrm{~h}$. After the impregnation methods, the bonding of metals in the wood was allowed to continue for about one week at room temperature. Table 1 summarizes the different impregnation methods on each sample and moisture $(\mathrm{H})$ content obtained by weight difference before and after drying. Therefore, the metal content in the treated wood was analyzed by inductively coupled plasma-mass spectrometry (ICP-MS), after digestion according to the reflux method provided by Helsen et al. [6]. The average concentration
Table 1

Treated and untreated wood.

\begin{tabular}{cllc}
\hline $\begin{array}{l}\text { Salts } \\
\text { treatments }\end{array}$ & Impregnated method & Sample name & $\mathrm{H}(\%)$ \\
\hline- & Untreated Wood & Bnt & 10.9 \\
$5 \% \mathrm{CCB}\{34 \%$ & Dipping treatment: the & Dipping Bt-CCB & 9.46 \\
$\mathrm{CuSO}+37 \%$ & samples were dipped & & \\
$\mathrm{KCr}\left(\mathrm{SO}_{4}\right)_{2}$ & into the impregnation & & \\
$+28.7 \%$ & solution for 24h for & & 8.61 \\
$\left.\mathrm{H}_{3} \mathrm{BO}_{3}\right\}$ & long-term dipping & & \\
& Pressure treatment: & Pressure & \\
& 10 min under vacuum & Bt-CCB & \\
& at 0.9 bar (absolute $)$ & & \\
& and 60 min under & & \\
& pressure of 8 bar in an & & \\
& autoclave & & \\
\end{tabular}

(ppm) of chromium, copper and boron in vacuum-pressure and dipping CCB-treated wood were shown in Table 2.

\subsection{Thermogravimetric analysis}

The apparatus used was a SETESYS evolution for TGA. It was equipped with SETERAM analysis software and SETSOFT 2000 program. The apparatus provides the continuous measurement of sample weight as a function of temperature and a provision was made for an electronic differentiation of the weight signal to give the rate of weight loss, the data are processed using Excel file. Thermogravimetric analyses of untreated wood and treated wood samples were carried out at the heating rate of $10^{\circ} \mathrm{C} / \mathrm{min}$ (which is approximately the same heating rate used for pyrolysis process) and a nitrogen flow rate of $20 \mathrm{ml} / \mathrm{min}$. A sample (56 mg) was heated from room temperature to $600^{\circ} \mathrm{C}$.

\subsection{Slow pyrolysis}

Slow pyrolysis of untreated and CCB-treated wood samples was carried out in a laboratory scale reactor. The reactor has a steel cylinder with an outer diameter of $14 \mathrm{~cm}$, an internal diameter of $9.5 \mathrm{~cm}$ and a height of $10 \mathrm{~cm}$. The sample of $10.6 \mathrm{~g}$ was weighed and placed in the reactor which was heated by an external electrical heater to its maximum power $(380 \mathrm{~W})$ for $70 \mathrm{~min}$. The samples was heated until maximum temperature at a heating rate of $10^{\circ} \mathrm{C} / \mathrm{min}$ and maintained for $20 \mathrm{~min}$, after which the experiment was terminated. A condenser was connected to the output of the reactor and the tar was condensed in a collector to be weighed. The charcoal collected in the reactor was weighed at the end of experiment. The temperature was measured every minute in the reactor using a type K thermocouple.

\subsection{Analytical methods}

\subsubsection{Metal analysis}

The chromium, the copper and the boron content in the charcoal and tar were analyzed by ICP-MS analysis. The metal content, expressed as percentage of the metal found in the charcoal or in the tar is calculated with Eq. (1). The percentage of the metal in gases is calculated by difference.

metal content $(\%)=\frac{[\text { metal }]_{\text {charcoal or tar }} \times m_{\text {charcoal or tar }}}{[\text { metal }]_{\text {treated wood }} \times m_{\text {treated wood }}}$

Table 2

Metal (Cu, Cr, B) content (mg metal/g of dried wood) of the samples.

\begin{tabular}{llll}
\hline Samples name & $\mathrm{Cu}(\mathrm{mg} / \mathrm{g})$ & $\mathrm{Cr}(\mathrm{mg} / \mathrm{g})$ & $\mathrm{B}(\mathrm{mg} / \mathrm{g})$ \\
\hline Dipping Bt-CCB & 21.36 & 6.02 & 9.7 \\
Pressure Bt-CCB & 11.06 & 4.03 & 6.2 \\
\hline
\end{tabular}


[metal $]_{\text {charcoal or tar }}$ and [metal $]_{\text {treated wood }}$ are the metal concentration (in wt\%) in charcoal or in tar and in treated wood respectively. $m_{\text {charcoal or tar }}$ and $m_{\text {treated wood }}$ are the masses of charcoal or tar and treated wood respectively.

\subsubsection{Lower heating value}

The higher heating value (HHV) of the charcoal and the tar is identified by the bomb calorimeter after a benchmark test on benzoic acid. The lower heating value (LHV) is calculated using the following formula:

$\mathrm{HHV}=\mathrm{LHV}+x_{\mathrm{H}} \times L_{\mathrm{H}_{2} \mathrm{O}}$

where $x_{\mathrm{H}}$ is mass fraction of hydrogen in the charcoal (or tar). It is obtained by elementary analysis of charcoal. $L_{\mathrm{H}_{2} \mathrm{O}}$ is latent heat of water $(2511 \mathrm{~kJ} / \mathrm{kg})$.

\section{Results and discussion}

\subsection{Thermogravimetric analysis of treated and untreated wood}

In the following discussion, the integral as well as the differential thermogravimetric curves are presented since both curves contain information which is relevant for understanding the thermal behavior of treated wood. The mass (TG) and derivative of mass (DTG) vs. temperature of treated wood and untreated wood are presented in Fig. 1.
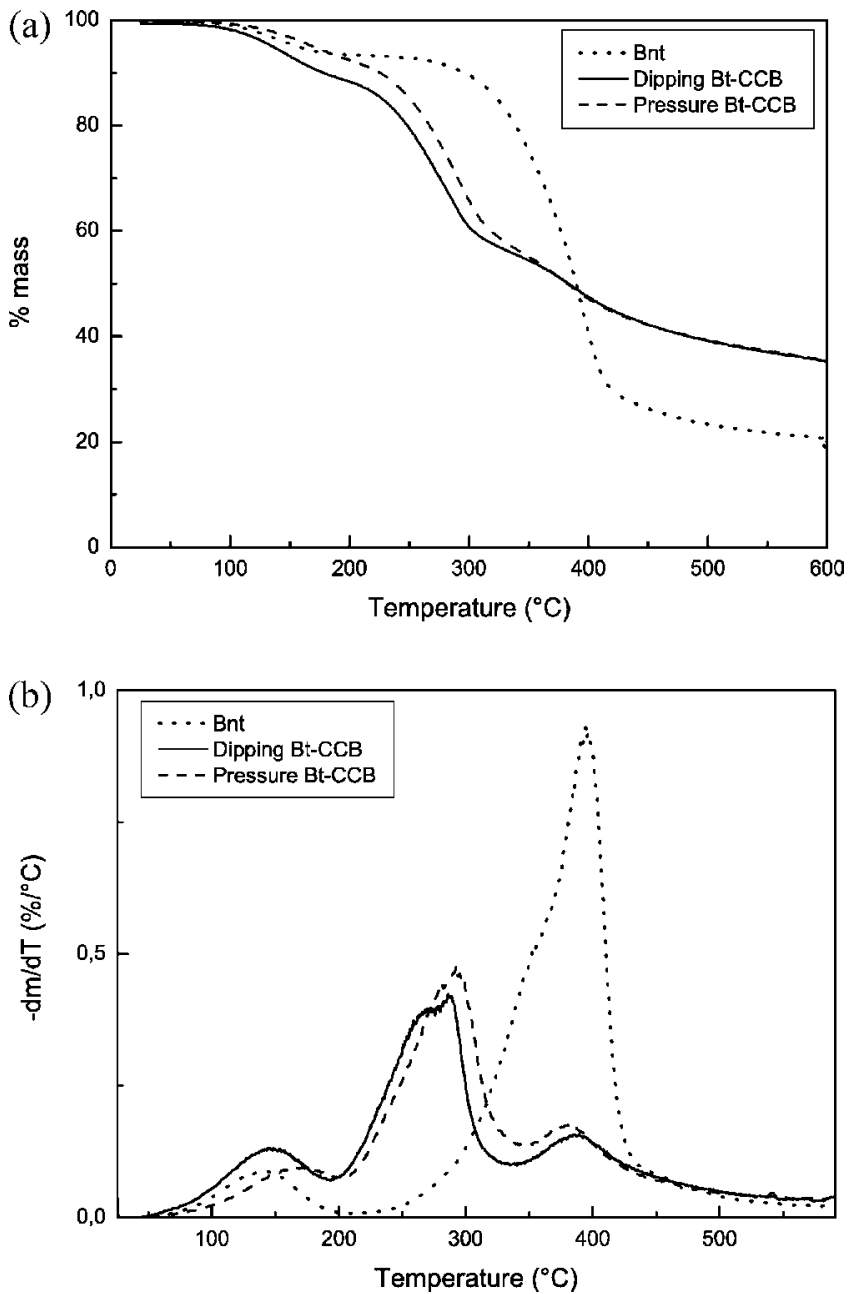

Fig. 1. Thermal behavior of untreated wood and CCB-treated wood. (a) TG curves and (b) DTG curves.
A comparison of the thermal behavior of untreated wood and treated wood (by vacuum-pressure and dipping method) showed a significant difference in mass degradation. At temperature below $100^{\circ} \mathrm{C}$, drying takes place with a corresponding peak in the DTG curve, representing the release of water vapor. The peaks observed at higher temperatures can be attributed to pyrolysis process of wood. The temperature threshold for which the pyrolysis of untreated wood starts is around $200^{\circ} \mathrm{C}$ and for treated wood the pyrolysis starts around $150^{\circ} \mathrm{C}$. This threshold is almost the same for both the treated woods. The temperature where the maximum rate of decomposition occurs $\left(T_{\text {peak }}\right)$ is around $390^{\circ} \mathrm{C}$ and the final charcoal yield is around 20\% for untreated wood. For CCBtreated wood by vacuum-pressure and dipping method, $T_{\text {peak }}$ is around $290^{\circ} \mathrm{C}$ which is lower than the value of untreated wood. The final yield of charcoal from treated wood is around 35\% at $600^{\circ} \mathrm{C}$ which is higher than the value obtained from untreated $\operatorname{wood}(20 \%)$.

In addition, by observing TG curves, unlike untreated wood, the both treated woods decomposed fast at lower temperature followed by a slower decomposition at high temperature. This investigation corresponds qualitatively with the TGA curves obtained in other studies with fire retardants inorganic salts. The resulting change in the nature of the pyrolysis reactions was reported there to be apparent in the higher rate of volatilization at the lower temperatures and the increased yield of the residual charcoal [11]. Further, the degradation of untreated and treated wood is done in two stages: a rapid degradation step and slower step (hence the presence of two peaks in Fig. 1(b)). It has been debated in the literature that the two regions of weight loss observed for wood pyrolysis is represented as a combination of individual decomposition of hemicelluloses and cellulose. In DTG curve of untreated wood, the lower temperature shoulder represents the decomposition of hemicelluloses and the higher temperature peak represents the decomposition of cellulose. Lignin decomposes slowly over a very broad range of temperatures. The decomposition of CCB-treated wood occurs in two steps. This shows that chromium, copper and boron content in the CCB treatment, interact with the wood components (cellulose, hemicelluloses, lignin) to form bonds during impregnation. As a result, these metals influence the thermal degradation of wood. This phenomenon is more pronounced for dipping CCB-treated wood than for vacuum-pressure CCB-treated wood in the temperature range of $200-280^{\circ} \mathrm{C}$ which corresponds to the decomposition of hemicelluloses and lignin. The opposite phenomenon is observed in temperature range of $290-400^{\circ} \mathrm{C}$ which corresponds to the decomposition of cellulose and lignin. This can be attributed to the higher amounts of metal in dipping CCB-treated wood compared to the amount of metals in vacuum-pressure CCB-treated wood (fixation of metals) and also in the chemical interaction between metals and components of wood (penetration of metals). Indeed, the impregnation process affects the final quantity of metals in treated wood. The penetration capacity, the fixation capacity, the retention capacity, the duration of impregnation and the distribution of metals in the wood are key parameters in the impregnation process [12]. Because of all these parameters there is a difference between the percentage of salts in the solution of CCB and the percentages of copper, chromium and boron in treated wood by vacuum-pressure method and by dipping method. The main practical difference between vacuumpressure method and dipping method is the depth of penetration of CCB salts in the wood. Taking into account the structure of wood components (lignin is the outer layer and the hemicelluloses are between lignin and cellulose), the metals interact more with lignin and hemicelluloses in case of dipping method and with lignin, hemicelluloses and cellulose in case of vacuum-pressure method. Thus in the temperature range of $200-290^{\circ} \mathrm{C}$, with high metals contents, the DTG peak of dipping treated wood is more high than the 
DTG peak of vacuum-pressure treated wood and the inverse in the temperature range of $290-400^{\circ} \mathrm{C}$. The two-stage decomposition was also observed by Zaror [13] who studied the low temperature pyrolysis of wood sample treated with sodium and potassium carbonates and chlorides. He defined a first stage characterization by a rapid evolution of volatiles which is controlled by chemical reactions; catalytic action of salts upon the pyrolysis reaction was postulated. It is important to notice that the cause of emerged DTG peaks of untreated wood is mineral matter naturally present in the biomass which catalyzes the pyrolytic decomposition in an unpredictable variety of ways. The second stage characterization by much slower rate of weight loss for which the mass transfer from interior of the sample to surroundings is likely to be the rate controlling step. The mass transfer becomes more important with an increase of salt content because the salt catalyzes the degradation mass of wood by increasing yield of charcoal at the expense of yield of tar and gas. The effects illustrated in this study are similar to previous work [13]. In fact, Richards and Zheng [14] attributed the very low 'DTG maximum peak' with transition metal $(\mathrm{Cu}$ and $\mathrm{Cr}$ in our case) to acid-catalyzed pyrolysis associated with sulfate ion.

\subsection{Pyrolysis products from untreated and treated wood}

Temperature profiles applied in pyrolysis experiment using the lab reactor are presented in Fig. 2. It is interesting to note the significant difference between the temperature profiles of untreated and both CCB-treated wood essentially in temperature ranges of $25-100^{\circ} \mathrm{C}$ and $150-350^{\circ} \mathrm{C}$. The difference observed in the first range can be attributed to the difference in moisture content of each sample. The difference in the second range can be attributed to the effect of metal ions in the decomposition of cellulose and hemicelluloses. It is seen that under the same operating conditions, final pyrolysis temperature for each sample is different. It can be attributed on one hand to thermal conductivity of metal ions presents in the wood [15] and the charring process which is highly exothermal. On the other hand, it can be explained by the combination effect of all metal ions and their amount in the CCB treatment as shown previously. The obtained results in Table 3 show that CCB compounds act as promoters of the pyrolysis reactions favoring the formation of charcoal. The results obtained from pyrolysis confirm those observed by TGA experiments.

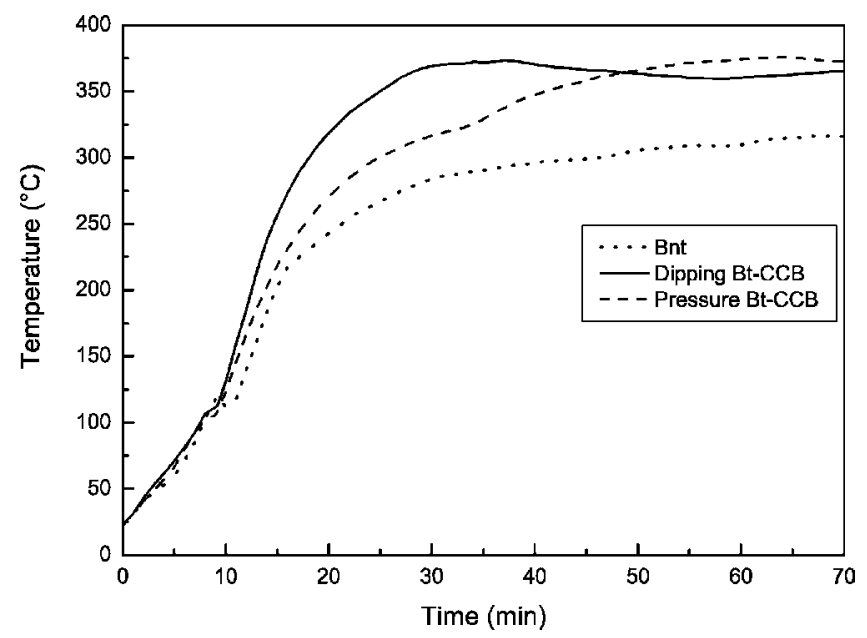

Fig. 2. Temperature profiles of untreated wood and CCB-treated wood during pyrolysis process.
Table 3

Pyrolysis products in weight percentage.

\begin{tabular}{lllll}
\hline & $\begin{array}{l}\text { Final } \\
\text { temperature }\left({ }^{\circ} \mathrm{C}\right)\end{array}$ & Charcoal (\%) & Tar (\%) & Gas (\%) \\
\hline Bnt & 316 & 31.64 & 38.29 & 30.10 \\
Dipping Bt-CCB & 358 & 41.25 & 37.21 & 21.54 \\
Pressure Bt-CCB & 372 & 41.47 & 36.09 & 22.42 \\
\hline
\end{tabular}

Table 4

Retention value of $\mathrm{Cu}, \mathrm{Cr}$ and $\mathrm{B}$ in charcoal.

\begin{tabular}{llll}
\hline & \multicolumn{4}{l}{ Mean retention values in charcoal (\%) } \\
\cline { 2 - 4 } & $\mathrm{Cu}$ & $\mathrm{Cr}$ & $\mathrm{B}$ \\
\hline Dipping Bt-CCB & 39.60 & 60.65 & 54.88 \\
Pressure Bt-CCB & 54.04 & 45.69 & 67.20 \\
\hline
\end{tabular}

\subsection{Metal analysis}

The distribution of heavy metals in the charcoal is given in Table 4. It can be seen that the contents of copper and boron are higher in charcoal of vacuum-pressure treated wood compare to dipping treated wood. The opposite phenomenon is observed for chromium. In the tar from vacuum-pressure treated wood and dipping treated wood, the metal content calculated on its total amount in the feedstock wood is only in the range of $10^{-3}$ to $10^{-4} \%$. Thus, the metals are emitted with the incondensable gases. From this experiment, the final pyrolysis temperature of CCB-treated wood at maximum power of the external heater is very difficult to recover all the metals in charcoal. Thereby, in a forthcoming study the thermal treatment and duration of the pyrolysis process will be performed.

\subsection{Analysis of heating value}

The results obtained from the analysis of lower and higher heating value for untreated and treated pyrolysis products are presented in Table 5. The LHV of the charcoal obtained from treated wood and that of untreated wood is approximately the same. The trends are opposite in the case of HHV of tar. Indeed, the amount of water in tar of untreated and CCB-treated wood is analyzed. For this, a mixture of $80 \mathrm{ml}$ of tar with $20 \mathrm{ml}$ of xylene (insoluble organic solvent in the water) was distilled. The xylene that evaporates at $143^{\circ} \mathrm{C}$ is an azeotropic mixture with water. After cooling, water and xylene were separate. The water fraction is determined volumetrically. The amount of water obtained from CCB-treated wood (89.08\%) increased by $15 \%$ compared to that from untreated wood (73.4\%). Thereby, chromium, copper and boron present in CCB-treated wood catalyze the dehydration and decarbonylation of cellulose and the degradation of lignin. It results in the increase of charcoal yields and in the increase of water. The results are interesting but investigation on pyrolysis gas should be performed for energy recovery of all pyrolysis products in future work.

Table 5

Calorific value of charcoal and tar of untreated and treated wood.

\begin{tabular}{lll}
\hline & \multicolumn{1}{l}{ HHV and LHV $(\mathrm{MJ} / \mathrm{kg})$} & \\
\cline { 2 - 3 } & LHV charcoal & HHV Tar \\
\hline Bnt & 32.86 & 7.6 \\
Dipping Bt-CCB & 29.64 & 2.7 \\
Pressure Bt-CCB & 30.13 & 2.7 \\
\hline
\end{tabular}




\section{Conclusion}

Treating wood with metal ions gives significant effect on its thermal degradation process. TGA and pyrolysis experiment showed that chromium, copper and boron present in salts of CCB induce the production of low tar and high charcoal yields. Furthermore, more boron and copper are captured in the charcoal compared to chromium at final temperature of pyrolysis process of wood impregnated by vacuum-pressure method. The opposite phenomenon is observed in the case of dipping method. The products obtained essentially charcoal and gas containing metals. Thus in a subsequent study, we will perform pyrolysis in order to increase the metals in the charcoal and to have a clean gas. It will consequently essential to extract the polluting elements in the charcoal to obtain clean products.

\section{References}

[1] N.W. Tame, B.Z. Dlugogorski, E.M. Kennedy, Formation of dioxins and furans during combustion of treated wood, Prog. Energy Combust. Sci. 33 (2007) 384-408.

[2] French Institute of Environmental, resources and waste rubric, edition of June, 2010.

[3] C. Yu-Wu, T. Townsend, H. Solo-Gabriel, Evaluation of thermal processes for CCA wood disposal in existing facilities, Report for Florida center for Solid and Hazardous waste Management, 2006, pp. 1-165.

[4] L. Helsen, E. Van del Bulck, Review of disposal technologies for chromated copper arsenate (CCA) treated wood waste, with detailed analyses of thermochemical conversion processes, J. Environ. Pollut. 134 (2005) 301-314.
[5] L. Helsen, E. Van den Bulk, S. Mullens, J. Mullens, Low-temperature pyrolysis wood: thermogravimetric analysis, J. Anal. Appl. Pyrolysis 52 (1999) 65-86.

[6] L. Helsen, E. Van den Bulck, K. Van den Broeck, C. Vandecasteele, Low temperature pyrolysis of CCA-treated wood waste: chemical determination and statistical analysis of metal input and output; mass balances, J. Waste Manag. 17 (1997) 79-86.

[7] L. Helsen, A. Hacala, Formation of metal agglomerates during carbonization of chromate cooper arsenate (CCA) treated wood waste: comparison between a lab scale and an industrial plant, J. Hazard. Mater. 3 (2006) 1438-1452.

[8] S. Whelte, D. Mejer, J. Moltran, O. Faix, The Impact of Wood Preservatives on the Flash Pyrolysis of Biomass. The Developments in Thermochemical Biomass Conversion, vol. 1, Blackie, Academic and Professional, London, 1997 pp. 206-219.

[9] Q. Fu, D.S. Argyropoulos, D.C. Tilotta, L.A. Lucia, Understanding the pyrolysis of CCA-treated wood. Part I: effect of metal ions, J. Anal. Appl. Pyrolysis 81 (2008) 60-64.

[10] M. Humar, M. Sentjurc, S.A. Amartey, F. Pohleven, Influence of acidification of $\mathrm{CCB}(\mathrm{Cu} / \mathrm{Cr} / \mathrm{B})$ impregnated wood on fungal copper tolerance, Chemosphère 58 (2005) 743-749.

[11] C. Di Blasis, C. Branca, A. Galgano, Flame retarding of wood by impregnation with boric acid-pyrolysis products and charcoal oxidation, J. Polym. Degrad. Stab. 92 (2007) 752-764.

[12] F. Chirra, Ohio Pesticide Applicator Training. Wood Preservation. The Ohio State University, Student Work Book, 1995, pp. 8-11.

[13] C.A. Zaror, Studies of the pyrolysis of wood at low temperatures, Thesis submitted for the degree of Doctor of Philosophy to University of London and for the Diploma of Imperial Collège, Department of Chemical Engineering and Chemical Technology, Imperial College, London, 1982.

[14] G.N. Richards, G. Zheng, Influence of metal ions and of salts on products from pyrolysis of wood: applications to thermochemical processing of newsprint and biomass, J. Anal. Appl. Pyrolysis 21 (1991) 133-146.

[15] H. Yang, R. Yan, H. Chen, D. Ho Lee, C. Zheng, Characteristics of hemicellulose cellulose and lignin pyrolysis, J. Fuel 86 (2007) 1781-1788. 